\title{
Best Practice Pembelajaran IPA-Biologi dalam Rangka Membangun Karakter Siswa Kelas VIII A di SMP N 4 Bojong
}

\author{
Ari Supriatun \\ Guru IPA di SMP N 4 Bojong \\ J1. Desa Randumuktiwaren, Bojong, Jawa Tengah \\ surat elektronik: Ariqoh5I4@gmail.com
}

\begin{abstract}
ABSTRAK
Pembelajaran merupakan suatu proses pengembangan potensi dan pembangunan karakter setiap peserta didik. Proses tersebut memberikan kesempatan kepada peserta didik untuk mengembangkan potensi sikap (spiritual dan sosial), pengetahuan, dan keterampilan yang diperlukan dirinya untuk hidup dan untuk bermasyarakat, berbangsa, serta berkontribusi pada kesejahteraan hidup umat manusia.

Penelitian ini menggunakan deskripsi. Populasi yang digunakan seluruh siswa kelas VIII A dengan jumlah 24. Data diambil dari hasil observasi dan tes pada materi sistem pencernaan manakan di kelas VIII A SMP N 4 Bojong. Analisis data dengan deskripsi kwantitatif.

Hasil penelitian menjelaskan bahwa pendekatan yang tepat dapat membantu menumbuhkan karakter dan memahamkan siswa atas materi yang diajarkannya. Melalui pengalaman pembelajaran menggunakan pendekatan saintifik mampu memberikan perubahan karakter dalam hal sikap disiplin, jujur, tanggung jawab, dan percaya diri. Selama kurun waktu 3 bulan terdapat perubahan signifikan atas karakter tersebut, yaitu percaya diri siswa yang semula 20,83\% menjadi $75 \%$, tanggung jawab dari 54,17\% menjadi $95,83 \%$, kejujuran siswa dari 66,7\% menjadi 87,5\%, dan kedisiplinan siswa dari 58,3\% menjadi 91,17\%. Dampak lain, juga mempengaruhi pemahaman siswa dan ketuntasan belajarnya telah melebihi Kreteria Ketuntasan Minimum/KKM 75 yaitu $87,5 \%$ atau sebanyak 2I siswa dinyatakan diatas KKM dan hanya 3 siswa (I2,5\%) masih dibawah KKM.
\end{abstract}

Kata kunci: Pembelajaran IPA, Karakter Siswa, Sistem Pencernaan Makanan

\section{Pendahuluan}

Siswa disetiap sekolah berasal dari berbagai latar belakang yang berbeda-beda. Siswa dalam satu kelas biasanya memiliki umur yang tidak jauh berbeda, namun mereka memiliki latar belakang yang berbeda. Hal tersebut dikarenakan mereka berasal dari lingkungan yang berbeda. Ada yang berasal dari keluarga berada, ada pula yang berasal dari keluarga kurang mampu. Ada yang pintar, ada pula yang kurang pandai. Sifat mereka pun berlainan satu sama lain. Sehingga didapatkan bahwa siswa-siswa dalam satu kelas memiliki latar belakang, sifat, dan karakter yang berbeda.

Terkait hal tersebut di atas, siswa di SMP N 4 Bojong, memiliki image siswa yang kemampuannya berada dibawah sekolah lain, dari segi nilai ujian nasional cenderung rendah yaitu antara 18,37 sampai 23,45. Sikap siswa yang cenderung diam dan kurang aktif, kurang mampu mengungkapan apa yang dia ketahui, siswa terkesan pasif dan suasana pembelajaran menjadi kurang menarik dan tidak interaktif, walaupun ada juga yang pandai diantara mereka. Selain hal tersebut, siswa SMP N 4 Bojong cenderung kurang mendapat perhatian dari orang tua khususnya dalam hal pendidikan karena orang tua mereka banyak yang bekerja diluar daerah, jadi siswa kebanyakan tidak serumah dengan orang tua bahkan banyak yang diititipkan dengan simbahnya, sehingga pengawasan pembelajaran siswa sangat kurang, yang menyebabkan siswa tidak memahami pentingnya belajar, sehingga berefek pada proses kegiatan belajar mengajar di dalam kelas. Dilihat dari segi geografisnya, SMP 4 Bojong termasuk SMP jauh dari keramaian karena terletak ditengah pelosok desa, kebiasaan masyarakat tersebut belum sadar akan pentingnya pendidikan, dengan kata lain mau sekolah saja sudah bagus, sehingga siswa mau berangkat itu sebuah hal yang luar biasa, hal tersebut mempengaruhi pola pikir dan tingkah laku siswa pada saat pembelajaran.

Dari beberapa gambaran karakteristik siswa, kebanyakan siswa kurang pantauan orang tua, 
kesadaran pendidikan yang kurang dan kurangnya dukungan lingkungan yang menyebabkan siswa banyak mengalami kendala dalam proses kegiatan belajar mengajar. Sering tidak konsentrasi, ramai/ gaduh dalam kelas, mengobrol dengan teman saat diterangkan guru, tidak mau mengerjakan sesuai tugasnya. Kebiasaan tersebut jika dibiarkan saja akan menimbulkan karakter yang kurang baik pada diri siswa.

Karakter dalam dunia pendidikan di era tahun 2014 menjadi bagian central dalam proses pendidikan yang ditekankan pemerintah. Karena ditengarai proses pembelajaran yang selama ini berjalan lebih fokus pada domain kognitif sehingga hal-hal yang terkait dengan domain afektif dan psikomotorik agak dikesampingkan. Ukuran keberhasilan siswa dalam proses belajar mengajar adalah pada perolehan nilai yang bisa diukur secara kwantitatif, sedangkan aspekaspek sikap dan ketrampilan dianggap sebagai bagian pelengkap kelulusan yang tidak begitu penting. Karena kesalahan dalam memahami hakekat pendidikan itu, para guru banyak yang ketakutan jika melaksanakan tugas tidak sesuai dengan juklak dan juknis yang telah digariskan oleh dinas pendidikan. Hal ini memberikan dampak tidak tergarapnya domain afektif dan psikomotorik dengan baik oleh para guru.

Sebenarnya dalam pembelajaran IPA, jika dilakukan dengan baik dan benar bisa sekaligus memberikan bekal pada siswa dalam tiga domain sekaligus yaitu kognitif, afektif, dan psikomotrik, yaitu dengan menerapkan konsep-konsep metode ilmiah pada pembelajaran IPA. Keterkaitan antara karakter siswa dengan pembelajaran dan mata pelajaran IPA sangat menarik untuk dijadikan bahan dalam tulisan ini, dengan berbekal pengalaman dalam membelajarkan IPA pada siswa SMP, maka persoalan yang diangkat dalam tulisan ini bagaimanakah menanamkan karakter pada siswa dalam proses pembelajaran IPA (Biologi) dengan menerapkan penggalan-penggalan dari pendekatan saintifik. Atas dasar itulah tulisan ini dikemas dalam artikel yang sifatnya best practice membentuk karakter siswa melalui pendekatan saintifik pada pembelajaran IPA.

\section{Metode Penelitian}

Penelitian ini menggunakan deskripsi. Populasi yang digunakan seluruh siswa kelas VIII A dengan jumlah 24. Data diambil dari hasil observasi dan tes pada materi sistem pencernaan manakan di kelas VIII A SMP N 4 Bojong. Analisis data dengan deskripsi kwantitatif.

\section{Hasil dan Pembahasan}

Karakater siswa tidak akan lepas dari konsep perkembangan siswa, yang mencakup perkembangan dari aspek fisik, aspek kognitif, dan aspek psikososial.
Perkembangan fisik atau yang disebut juga pertumbuhan biologis meliputi perubahan-perubahan dalam tubuh dan perubahan-perubahan dalam cara-cara individu dalam menggunakan tubuhnya serta perubahan dalam kemampuan fisik.

Perkembangan kognitif adalah salah satu aspek perkembangan peserta didik yang berkaitan dengan pengertian, yaitu semua proses psikologi yang berkaitan dengan bagaimana individu mempelajari dan memikirkan lingkungannya. Perkembangan kognitif ini meliputi perubahan pada aktivitas mental yang berhubungan dengan persepsi, pemikiran, ingatan, keterampilan berbahasa, dan pengolahan informasi yang memungkinkan seseorang memperoleh pengetahuan, memecahkan masalah, dan merencanakan masa depan, atau semua proses psikologi yang berkaitan dengan bagaimana individu mempelajari, memperhatikan, mengamati, memperkirakan, menilai dan memikirkan lingkungannya.

Perkembangan psikososial adalah proses perubahan kemampuan peserta didik untuk menyesuaikan diri dengan lingkungan sosial yang lebih luas. Dalam proses perkembangan ini peserta didik diharapkan mengerti orang lain, yang berarti mampu menggambarkan ciricirinya, mengenali apa yang dipikirkan, dirasakan dan diinginkan serta dapat menempatkan diri pada sudut pandang orang lain, tanpa kehilangan dirinya sendiri, meliputi perubahan pada relasi individu dengan orang lain, perubahan pada emosi dan perubahan kepribadian.

Berdasarkan yang sudah diungkapkan di bagian pendahuluan, karakter siswa di SMP N 4 Bojong sangat variatif yang dipengaruhi oleh latar belakang keluarga dan faktor lingkungan. Khusus pada aspek kedisiplinan, kejujuran, tanggungjawab, dan percaya diri sebagaimana yang di tuntut dalam kompetensi inti dalam kurikulum 2103, keempat karakter yang diharapkan tersebut masih sangat jauh dari yang diharapkan. Secara kualitatif keempat sikap tersebut pada awalnya tidak nampak pada siswa kelas VIII A, siswa sering terlambat masuk kelas, banyak yang tidak jujur didasarkan pada aduan siswa lain pada guru, banyak yang tidak mengerjakan tugas atau tidak bertanggungjawab jika diberi amanah, dan banyak yang minder atau tidak percaya diri.

Lebih jelasnya tentang karakter siswa yang kurang baik tersebut dapat dijelaskan dengan data kwantitatif yang ditunjukan dengan jumlah total siswa dalam kelas VIII A 24 siswa, dari keempat karakter siswa tersebut sudah memiliki dasar karakter yang baik sejak kelas VII, dengan data Tabel I berikut.

Tabel I. Gambaran Awal Karakter Siswa

\begin{tabular}{llll}
\hline $\begin{array}{l}\text { Fokus Karakter } \\
\text { yang diamati }\end{array}$ & $\begin{array}{l}\text { Data Awal } \\
\text { Sikap/Karakter } \\
\text { Siswa }\end{array}$ & $\begin{array}{l}\text { Persentase } \\
\text { Sikap/Karakter yang } \\
\text { perlu ditingkatkan }\end{array}$ \\
\cline { 2 - 3 } & + & - & \\
\hline Kedisiplinan & I0 & I4 & 58,3 \\
\hline Kejujuran & 8 & I6 & 66,7 \\
\hline Tanggungjawab & I & I3 & 54,17 \\
\hline Percaya diri & 5 & I9 & 20,83 \\
\hline
\end{tabular}


Mengacu pada Tabel I diatas, kondisi karakter siswa yang paling rendah adalah sikap rasa percaya diri siswa yang sangat rendah $(20,83 \%)$ kemudian diikuti dengan rasa tanggungjawab yang belum terbangun $(54,17 \%)$ dan kedisiplinan siswa yang masih kurang $(58,3 \%)$. Untuk sikap kejujuran karena berangkat dari latar belakang dari pedesaan karakter jujur masih bisa dikatakan cukup baik. Secara lebih jelas gambaran awal tentang karakter siswa jika dikwantitatifkan dapat juga dilihat dalam Gambar I berikut.

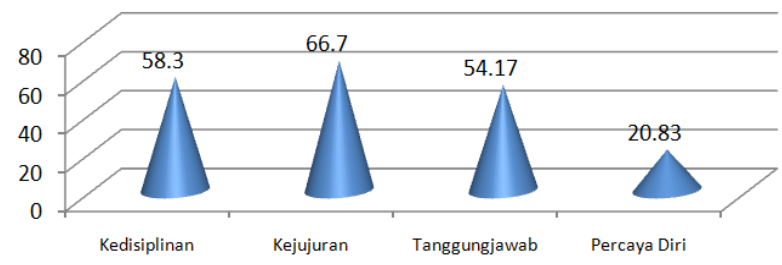

Gambar I. Grafik Gambaran Awal Karakter Mahasiswa

Berdasarkan data analisis awal kondisi sikap/karakter siswa pada aspek kedisiplinan, kejujuran, tangggungjawab, dan percaya diri siswa kelas VIII A di SMP N 4 Bojong tersebut menuntut guru IPA untuk berpikir dan bekerja lebih cerdas dan keras agar dapat memberikan bekal sesuai dengan yang diharapkan. Banyak kendala yang menghambat dalam penanaman karakter siswa di SMP N 4 Bojong, mulai dari kendala dimusuhi teman sejawat, peneguran oleh kepala sekolah, dan bahkan juga dimusuhi oleh para siswa pada saat diawal-awal. Karena banyak yang menentang dan tidak setuju jika tabiat dan kebiasaan yang sudah terlalu sering dilalukan ada yang menegur dan merubahnya.

Fenomena/fakta tersebut di atas merupakan hal yang bersifat wajar karena jika dilihat dari teori perkembangan yang dituliskan oleh banyak ahli perkembangan peserta didik, anak usia sekolah menengah (SMP) berada pada tahapan perkembangan pubertas (I0 -I4 tahun ), dengan karakteristik, yaitu : I) terjadinya ketidakseimbangan proposi tinggi dan berat badan; 2) mulai timbulnya ciri - ciri seks sekunder; 3) kecenderungan ambivalensi, antara keinginan untuk bebas dari dominasi dengan keinginan bergaul, serta keinginan untuk bebas dari dominasi kebutuhan bimbingan dan bantuan dari orang tua; 4) senang membandingkan kaedah-kaedah, nilai-nilai etika atau norma dengan kenyataan yang terjadi dalam kehidupan orang dewasa; 5) mulai mempertanyakan secara skeptis mengenai eksistensi dan sifat kemurahan dan keadilan Tuhan; 6) reaksi dan ekspesi emosi masih labil; dan 7) mulai mengembangkan standar dan harapan terhadap perilaku diri sendiri yang sesuai dengan dunia sosial.

Pengalaman yang dilakukan untuk menanamkan karakter pada diri siswa yang mendapat banyak tantangan dan hambatan tersebut, tidaklah menyurutkan semangat untuk memberikan tindakantindakan agar terwujudnya keseimbangan dari hasil pendidikan, maka tindakan yang diterapkan guru IPA untuk menanamkan karakter dalam pembelajarannya dan pernah diujicobakan dalam kelas yang diampunya, antara lain: I) menerapkan model pembelajaran yang memisahkan siswa pria dan wanita ketika membahas topik-topik yang berkenaan dengan anatomi dan fisiologi; 2) memberikan kesempatan kepada siswa untuk menyalurkan hobi dan minatnya melalui kegiatan-kegiatan yang positif; 3) menerapkan pendekatan pembelajaran yang memperhatikan perbedaan individu; 4) meningkatkan kerja sama untuk mengembangkan potensi siswa; dan 5) memberikan kesempatan kepada siswa untuk belajar bertanggung jawab.

Usaha-usaha tersebut memberikan hasil yang nyata dengan adanya peningkatan capaian karakter dari 24 siswa dikelas VIII A menunjukkan adanya perubahan sikap pada diri siswa, yaitu sikap disiplin, jujur, tanggungjawab dan percaya diri. Penilaian karakter pada materi sistem pencernaan ini disiplin, jujur, tanggung jawab, dan percaya diri, dapat diambil dari:

I.Disiplin, nilai karakter disiplin diambil dari awal proses pembelajaran sampai akhir proses pembelajaran, dengan melihat siswa mgerjakan tugas tepat sesuai waktu, masuk dikelas tepat sesusai waktu.

2. Jujur, nilai karakter jujur diambil dari siswa dilihat dari proses pengolahan data dan pengamatan,

3. Tanggung jawab, dinilai dari proses mengerjakan tugas dalam kelompoknya, yang beripa menjawab / mengerjakan LKS dan menyajikan hasikan hasil diskusi

4. Percaya diri, di nilai pada saat presentasi hasil hasil percobaan dan presentasi hasil kelompok, karena setiap kelompok wajib mempresentasikan hasil kelompoknya masing-masing dan berani memberikan tanggapan dan masukkan saat diskusi dan presentasi.

Keempat sikap tersebut pada awalnya tidak nampak pada siswa kelas VIII A, siswa sering terlambat masuk kelas, banyak yang tidak jujur didasarkan pada aduan siswa lain pada guru, banyak yang tidak mengerjakan tugas atau tidak bertanggungjawab jika diberi amanah, dan banyak yang minder atau tidak percaya diri. Namun setelah guru memberikan treatment dengan menerapkan penggalan pendekatan saintifik dalam pembelajaran IPA pada materi pencernaan makanan, dalam kurun waktu 3 bulan yang dimulai dari bulan Agustus 2014 sampai dengan Oktober 2014 sudah ada perubahan sikap/karakter siswa tersebut meningkat. Data-Data tersebut dapat ditunjukan dalam Tabel 2 berikut.

Tabel 2. Perubahan Sikap/Karakter Siswa Selama 3 Bulan

\begin{tabular}{llll}
\hline Fokus karakter & $\begin{array}{l}\text { Data Hasil } \\
\text { yang diamati }\end{array}$ & $\begin{array}{l}\text { Pengamatan Pasca } \\
\text { Pembelajaran } \\
\text { (Treatment) }\end{array}$ & $\begin{array}{l}\text { Perubahan } \\
\text { Sikap (\%) }\end{array}$ \\
\cline { 2 - 3 } & Y & T & \\
\hline Kedisiplinan & 22 & 2 & $9 \mathrm{I}, \mathrm{I7}$ \\
\hline Kejujuran & $2 \mathrm{I}$ & 3 & 87,5 \\
\hline Tanggungjawab & 23 & $\mathrm{I}$ & 95,83 \\
\hline
\end{tabular}




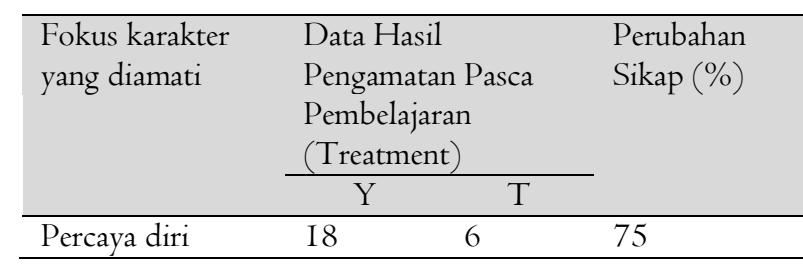

Perubahan yang paling menonjol secara kwantitatif terjadi pada rasa percaya diri siswa yang semula $20,83 \%$ menjadi $75 \%$. Juga diikuti dengan perubahan sikap/karakter siswa yang lain, seperti tanggung jawab dari $54,17 \%$ menjadi $95,83 \%$, kejujuran siswa dari $66,7 \%$ menjadi $87,5 \%$, dan kedisiplinan siswa dari 58,3\% menjadi 91,I7\%. Selanjutnya perubahan sikap siswa tersebut akan nampak jelas jika dilihat dalam Gambar 2 berikut.

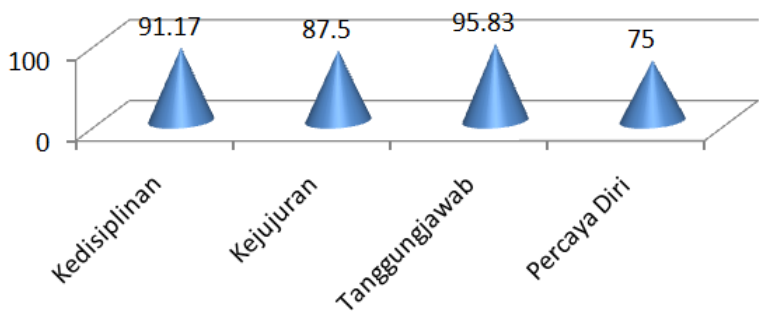

Gambar 2. Grafik Perubahan Sikap dalam 3 Bulan

Dalam kurun waktu 3 bulan (Agustus sd Oktober 20I4), guru memberikan treatment dalam pembelajaran, dari manajemen kelas, penerapan bagian/penggalan pendekatan santifik untuk membelajarkan materi pencernaan makanan pada siswa kelas VIII A terdapat perubahan yang signifikan dari sisi afektif siswa, khususnya pada aspek kedisplinan, kejujuran, tanggungjawab, dan percaya diri. Hasil peningkatan perubahan tersebut jika dikomparatifkan secara kwantitatif dapat dijelaskan dalam tabel 3 berikut.

Tabel 3. Persentase peningkatan atas perubahan sikap/karakter siswa

\begin{tabular}{lccl}
\hline \multirow{2}{*}{$\begin{array}{l}\text { Fokus karakter } \\
\text { yang diamati }\end{array}$} & \multicolumn{2}{l}{$\begin{array}{l}\text { PerubahanPeningkatan } \\
\text { karakter Siswa }\end{array}$} & $\begin{array}{l}\text { Persentase } \\
\text { Peningkatan }\end{array}$ \\
\cline { 2 - 3 } & Awal & Akhir & \\
\hline Kedisiplinan & 58,3 & 91,17 & 32,87 \\
\hline Kejujuran & 66,7 & 87,5 & 20,8 \\
\hline Tanggungjawab & 54,17 & 95,83 & 41,66 \\
\hline Percaya diri & 20,83 & 75 & 54,17 \\
\hline
\end{tabular}

Berdasarkan Tabel 3 nampak jelas dalam kurun waktu 3 bulan dengan pendekatan pembelajaran saintifik telah mampu menghantarkan perubahan sikap/karakter siswa pada sikap percaya diri siswa naik menjadi 54,17\%, tanggungjawab naik 4I,66\%, kedisiplinan siswa dalam mengikuti pelajaran naik $32,87 \%$, dan kejujuran siswa walau sikap awal sudah cukup baik tetap ada kenaikan sebesar 20,8\%. Gradasi peningkatan tersebut secara lebih jelas dapat dilihat pada Gambar 3.

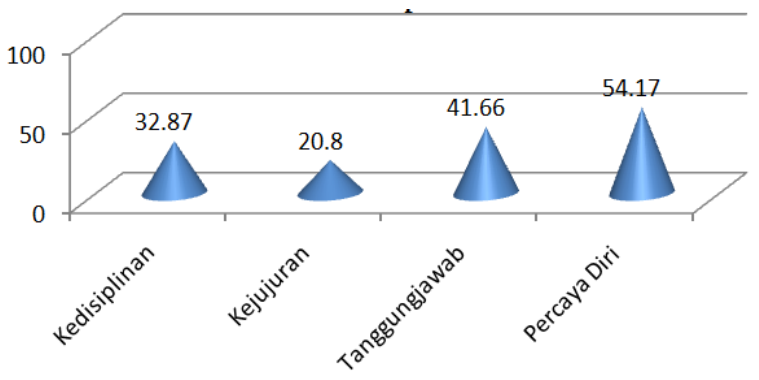

Gambar 3. Perubahan Sikap dalam 3 Bulan

Berdasarkan Gambar 3 di atas, perubahan yang dratis diperoleh dari sikap percaya diri yang naik $54,17 \%$ dalam kurun waktu 3 bulan. Percaya diri terbentuk karena guru berhasil menciptakan suasana belajar dan pembelajaran yang menjadikan siswa nyaman dan tidak membeda-bedakan siswa satu dengan yang lain, sehingga dalam proses pembelajaran siswa saling membantu siswa lain yang masih belum paham terhadap materi pelajaran. Rasa percaya diri yang kuat ternyata mampu memunculkan sikap empati para siswa di kelas VIII A. Hal ini sesuai dengan yang dikatakan Santrock (1998) bahwa perkembangan kehidupan sosial remaja juga ditandai dengan gejala meningkatnya pengaruh teman sebaya dalam kehidupan mereka, sebagian besar waktunya dihabiskan untuk berhubungan atau bergaul dengan teman - teman sebaya mereka, sehingga menunjukkan hubungan yang positif dengan teman sebaya diasosiasikan dengan penyesuaian sosial yang positif.

Hartup (1982) juga mencatat bahwa pengaruh teman sebaya yang harmonis selama masa remaja, dihubungkan dengan kesehatan mental yang positif pada usia setengah baya. Secara lebih rinci, Kelly dan Hasnen (I987) menyebutkan 6 fungsi positif dari teman sebaya, yaitu:

I. Mengontrol impuls-impuls agresif. Melalui interaksi dengan teman sebaya, remaja belajar bagaimana memecahkan pertengahan - pertengahan dengan cara - cara yang lain selain dengan tindakan agresi langsung.

2. Memperoleh dorongan emosional dan sosial serta menjadi lebih independen. Teman - teman dan kelompok teman sebaya memeberikan dorongan bagi remaja untuk mengambil peran dan tenggung jawab baru mereka. Dorongan yang diperoleh remaja dari teman-teman sebaya mereka ini akan menyebabkan berkurangnya ketergantungan remaja pada dorongan keluarga mereka.

3. Meningkatkan keterampilan-keterampilan sosial, mengembangkan kemampuan penalaran, dan belajar untuk mengekspresikan perasaan-perasaan dengan cara-cara yang lebih matang. Melalui percakapan dan perdebatan dengan teman sebaya, remaja belajar mengekspresikan ide-ide dan perasaan-perasaan serta mengembangkan kemampuan mereka memecahkan masalah.

4. Mengembangkan sikap - sikap seksual dan tingkah laku peran jenis kelamin terutama dibentuk melalui 
interaksi dengan teman sebaya. Remeja belajar mengenai tingkah laku dan sikap - sikap yang mereka asosiasikam dengan menjadi laki - laki dan perempuan muda

5. Memperkuat penyesuaian moral dan nilai - nilai. Umunya orang dewasa menhajarkan kepada anak anak mereka tentang apa yang benar dan apa yangb salah. Dalam kelompok teman sebaya, remaja mencoba mengambil keputusan atas diri mereka sendiri. Remaja mencoba mengambil keputusan atas diri mereka sendiri. Remaja mngevaluasi nilai - nilai yang dimilikinya dan yang dimiliki oleh teman sebayanya, serta memutuskan mana yang benar. Proses mengavaluasi ini dapat membantu remaja mengembangkan kemampuan penalaran moral

6. Meningkatkan harga diri. Menjadi orang yang disukai oleh sejumlah besar teman - teman sebayanya membuat remaja merasa enak atau senang tentang dirinya.

Untuk memberlajarkan materi sistem pencernaan makanan pada siswa SMP yang memiliki karakteristik yang unik seperti yang ada di SMP N 4 Bojong, kunci keberhasilan awal adalah pada kreatifitas guru. Materi sistem pencernaan makanan merupakan bagian dari pelajaran IPA yang memiliki karakteristik pada pengalaman langsung untuk mengembangkan kompetensi agar peserta didik mampu memahami alam sekitar melalui proses "mencari tahu" dan "berbuat", hal ini akan membantu peserta didik untuk memperoleh pemahaman yang lebih mendalam.

Keterampilan dalam mencari tahu atau berbuat tersebut dinamakan dengan keterampilan proses penyelidikan atau "inquiry skills" yang meliputi mengamati, mengukur, menggolongkan, mengajukan pertanyaan, menyusun hipotesis, merencanakan eksperimen untuk menjawab pertanyaan, mengklasifikasikan, mengolah, dan menganalisis data, menerapkan ide pada situasi baru, menggunakan peralatan sederhana serta mengkomunikasikan informasi dalam berbagai cara, yaitu dengan gambar, lisan, tulisan, dan sebagainya. Melalui keterampilan proses dikembangkan sikap dan nilai yang meliputi rasa ingin tahu, jujur, sabar, terbuka, tidak percaya tahayul, kritis, tekun, ulet, cermat, disiplin, peduli terhadap lingkungan, memperhatikan keselamatan kerja, dan bekerja sama dengan orang lain. Oleh karena itu pembelajaran IPA di sekolah sebaiknya:

I. Memberikan pengalaman pada peserta didik sehingga mereka kompeten melakukan pengukuran,

2. Menanamkan pada peserta didik pentingnya pengamatan empiris dalam menguji suatu pernyataan ilmiah (hipotesis). Hipotesis ini dapat berasal dari pengamatan terhadap kejadian sehari-hari yang memerlukan pembuktian secara ilmiah,

3. Latihan berpikir kuantitatif yang mendukung kegiatan belajar matematika, yaitu sebagai penerapan matematika pada masalah-masalah nyata yang berkaitan dengan peristiwa alam,

4. Memperkenalkan dunia teknologi melalui kegiatan kreatif dalam kegiatan perancangan dan pembuatan alat-alat sederhana maupun penjelasan berbagai gejala dan keampuhan IPA dalam menjawab berbagai masalah.

Membelajarkan materi sistem pencernaan pada makanan ini berhubungan dengan proses penyerapan pada usus halus yang dilakukan pada siswa kelas VIII A, guru memilih strategi dengan bantuan model penyerapan usus berupa kain handuk dan kain katun sebagai alat bantu membelajarkan, karena jika hanya menggunakan charta/gambar sistem pencernaan maka siswa kesulitan untuk memahami materi ini jika hanya berimajinasi. Alasan guru memilih alat bantu tersebut bahwa materi sistem pencernaan makanan merupakan materi biologi yang seharusnya bisa disampaikan kepada siswa secara mudah dengan bantuan alat peraga yang sederhana dengan menggunakan kain handuk dan katun sehngga siswa dapat dengan mudah membandingkan daya serap usus dengan kedua alat peraga tersebut. jika metode sebelum dengan menggunakan gambar/carta siswa kurang memahami tetapi setelah menggunakan pendekatan saintifik inquiry skills yang berpusat siswa yang aktif mencari tahu maka siswa lebih mudah memahami. Apalagi sebelum mulai pembelajaran siswa dirangsang dulu dengan pertanyaan dan tayangan video yang berhubungan dengan cara penyerapan usus.

Mengemas pembelajaran dengan menerapkan pendekatan saintifik dan memberikan rangsangan pada siswa melalui pemberian pertanyaan untuk menggali potensi siswa untuk lebih memahami materi pembelajaran, kemudian ditambahkan dengan memperlihatkan tayangan vidio yang berhubungan dengan kerja usus dalam sistem pencernaan, dengan seperti ini pembelajaran terkesan santai menarik dan tidak monoton yang akhirnya membuat siswa menjadi santai dan berani tambil berbicara, bertanya, dan mengungkapkan ide gagasan yang diketahui dari proses pembelajaran dikelas, misalnya mereka tertarik tatkala dibawakan kain handuk dan katun, ternyata mengundang mereka tuk bertanya "untuk apa kain itu, apakah usus seperti kain handuk, atau seperti kain katun?" dan masih banyak pertanyaan yang terlontar dari siswa dikelas yang menyebabkan kelas menjadi hidup dan aktif serta materi pembelajaran menjadi menarik untuk diikuti.

Hal lain yang tidak boleh dilupakan dalam pembelajaran dikelas IPA adalah manajemen kelas. Manajemen kelas yang baik harus sesuai dengan kondisi siswa dan karakteristik materi pembelajaran IPA yang dalam hal ini pada materi sistem pencernaan makanan. Guru mampu menyampaikan bahan pelajaran dan dapat diterima oleh peserta didik dengan baik, dan mampu mengkondisikan siswa sesuai tujuan 
pembelajaran agar siswa tertarik untuk melakukan proses kegiatan belajar mengajar sehingga siswa mampu memahami materi tersebut yang ditunjukan dengan tingginya nilai tes tertulis, dan sedikitnya siswa yang tidak tuntas, karena selama ini siswa cenderung pasif, tidak mau berpendapat dan tidak bisa mengungkapkan ide gagasan yang siswa ketahui, mereka cenderung diam walaupun sebenarnya siswa ingin berbicara mengungkapkan ide tapi tidak berani tampil, bahkan siswa laki-laki cenderung ramai sendiri sehingga pembelajaran tidak kondusif dan terkesan ramai atau gaduh di kelas.

Selain itu, untuk mengelola kelas dengan baik guru juga mengajak seluruh siswa untuk berkompetisi dan menyampaikan ide ato gagasan dalam materi sistem pencernaan dan mampu membuat kesimpulan sesuai tujuan pembelajaran, sehingga dengan manajemen yang baik diharapkan siswa tuntas dalam tes tertulis, dengan mendapat nilai minimal KKM atau lebih besar dari KKM. Proses pembelajaran IPA pada sistem pencernaan sangat tergantung bagaimana guru dalam menyampaikan materi tersebut dan memberi gambaran yang benar kepada siswa tidak hanya siswa diminta untuk berimajinasi tentang organ-organ pencernaan, tetapi guru harus mampu menyampaikan dengan secara utuh dan benar walaupun hanya dengan menggunakan alat peraga setidaknya siswa akan terbantu untuk memahami dengan jelas isi dari materi tersebut. Sebelum pembelajaran dilakukan guru menyiapkan RPP dan LKS yang akan digunakan serta, alat dan bahan yang harus di siapkan oleh siwa agar pembelajaran berjalan lancar dan sesuai tujuan pembelajaran yaitu siswa mengetahui cara kerja penyerapan usus halus. Dengan menggunakan alat peraga handuk dan kain katun, sehingga siswa mampu memehami proses penyerapan usus halus dengan perbandingan penyerapan pada kedua kain tersebut.

Gambaran pelaksanaan proses pembelajaran yang dilakukan dapat dideskripsikan dalam tiga tahapan, yaitu: tahap proses persiapan (pre-active), tahap pelaksanaan (inter-active), dan tahap penutup (postactive), sebagai berikut:

\section{Tahap Persiapan (Inter-Active)}

Sebelum memulai proses pembelajaran di kelas maka sebagai guru perlu mempersiapkan, perangkat pembelajaran yang akan digunakan, baik itu RPP (Rencana Pelaksanaan Pembelajaran ), materi pembelajaran, media pembelajaran, startegi pembelajaran, dan mental yang terkait dengan personal guru.

\section{Tahap pelaksanaan (Inter-active)}

Deskripsi tahap pelaksanaan sebagaimana tergambar dalam langkah pembelajaran yang terangkum pada tabel berikut.
a. Tahap Pendahuluan (20 menit)
Menciptakan situasi (stimula pada siswa), dengan jalan:

I) menyiapkan peserta didik untuk belajar

2) guru melakukan pemusatan perhatian:
(a) guru memperlihatkan video model penyerapan usus halus
(b) guru memancing peserta didik

3) agar mengajukan pertanyaan yang berkaitan dengan video model penyerapan di usus halus

I) guru melakukan apersepsi sesuai dengan video yang ditunjukkan
2) guru menyampaikan tujuan belajar dan cakupan materi

\section{b. Tahap Kegiatan Inti (80 menit)} learning:

Langkah-langkah penerapan model discovery

I) Pembahasan tugas dan identifikasi masalah, dilakukan dengan : Menyampaikan informasi tentang kegiatan yang akan dilakukan yaitu pembuatan model penyerapan usus halus, dan membagi peserta didik menjadi 8 kelompok

2) Observasi, guru memantau kegiatan : Diskusi kelompok untuk mengkaji LKS bagaimana cara membuat model penyerapan usus halus melalui percobaan dengan kain handuk dan kain katun untuk menunjukkan perbedaan penyerapan pada usus halus.

3) Pengumpulan data, dengan melakukan percobaan pembuatan model penyerapan usus halus, peserta didik mengamati percobaan dan mencatat data pada kolom yang tersedia pada LKS

4) Pengolahan data, dan analisis; mengolah dan menganalisis data percobaan, berdiskusi untuk menjawab pertanyaan yang ada di LKS

5) Verifikasi; Presentasi hasil percobaan, dan diskusi model penyerapan usus halus berdasarkan data hasil percobaan dan mencocokan dengan konsep pada buku sumber; peserta didik mempresentasikan hasil kerja kelompok

6) Generalisasi; membuat kesimpulan tentang prinsip-prinsip dan metode model penyerapan usus halus

c. Tahap Penutupan (20 menit)

I) Peserta didik dan guru mereview hasil kegiatan pembelajaran

2) Guru memberikan penghargaan pada kelompok yang kinerjanya baik dengan aplaus tepuk tangan dan pujian

3) Pemberian tugas untuk mempelajari pemanfaatan model penyerapan makanan di usus halus

\section{Tahap Penutup (Post-Active)}

Untuk mengetahui berhasil tidaknya pembelajaran pada materi sistem pencernaan makan maka perlu diadakan evaluasi melalui tes lisan atau tertulis atau praktek, untuk evaluasi pada proses 
pembelajaran ini dengan menggunakan tertulis dengan menjawab pertanyaan tentang sistem pencernaan yang berfokus pada proses penyerapan usus halus. Dengan nilai kriteria ketuntasan minimal ( $\mathrm{KKM}$ ) 75, dari 24 siswa yang ikut tes tulis ada 3 siswa yang belum tuntas. Perolehan nilai sebagai penciri ketuntasan belajar dapat dijelaskan pada tabel 4 berikut.

\section{Simpulan}

Melalui pengalaman pembelajaran yang sudah dilakukan dengan menggunakan pendekatan saintifik ternyata mampu memberikan perubahan sikap/karakter siswa kelas VIII A di SMP N 4 Bojong dalam hal sikap disiplin, jujur, tanggung jawab, dan percaya diri. Dalam kurun waktu 3 bulan terdapat perubahan signifikan atas karakter tersebut, yaitu percaya diri siswa semula $20,83 \%$ menjadi $75 \%$, tanggung jawab dari 54,17\% menjadi 95,83\%, kejujuran siswa dari $66,7 \%$ menjadi $87,5 \%$, dan kedisiplinan siswa dari 58,3\% menjadi 91,17\%. Dampak yang lainnya meningkatnya pemahaman siswa hingga mencapai ketuntasan belajar lebih dari KKM yang telah ditentukan 75 yaitu naik sebesar 87,5\% atau sebanyak $2 \mathrm{I}$ siswa dinyatakan diatas KKM dan hanya 3 siswa (I2,5\%) yang masih dibawah KKM dengan waktu tempuh dalam 3 bulan.

\section{Daftar Pustaka}

Albertus, Doni Koesoema. 2007. Pendidikan Berkarakter, Gramedia Widiasarana, Jakarta

Anonim. 2013. Bahan Diklat Guru Diklat Guru Dalam Rangka Implementasi Kurikulum 2013. Mata Diklat: 2. Analisis Materi Ajar Jenjang: SD/SMP/SMA Mata Pelajaran: Konsep Pendekatan Scientific. Kementerian Pendidikan Dan Kebudayaan Tahun 2013.

http://akhmadsudrajat.files.wordpress.com/2013/07/ pendekatan-saintifik-ilmiah-dalam-pembela... diunduh 22 Maret 2014

Djamaroh, syaiful Bahri. 2000. Guru dan Anak Dididk dalam Interaksi Edukatif. Jakarta Rineka Cipta.

Gulo, W. 1982. Strategi Belajar Mengajar. Jakarta : Grasindo

http://aadesanjaya.blogspot.com/2010/I0/hakikatpembelajaran-ipa.html diakses pada 03 Nopember $201 \mathrm{I}$

http://anwarholil.blogspot.com/2009/0I/hakikatpembelajaran-ipa.html diakses pada 03 Nopember $201 \mathrm{I}$

http://dakata.wordpress.com/2014/04/I3/PembentukanKarakter-Individu.html.

http://Pustaka.Pandani.web.id/2013/03/PengertianKarakter.html.

Kamisa, I997. Kamus lengkap Bahasa Indonesia. Surabaya: Kartika.
Masnur Muslikh. 2007. KTSP Kurikulum Tingkat Satuan Pendidikan. Jakarta : PT Bumi Aksara.

Muhmmad Joko Susilo. 2007. Kurikulum Tingkat Satuan Pendidikan. Manajemen Pelaksanaan dan Kesiapan Sekolah Menyongsongnya. Yogyakarta: Pustaka Pelajar.

Rahman, Maman. 1998. Manajemen Kelas. Jakarta: Departemen Pendidikan dan Kebudayaan Direktorat Jendral Pendidikan Tinggi 